\title{
Assessment of the Impact of the Level of Disclosure of Mandatory Non-Financial Information in Public Annual Reports on the Investment Attractiveness of a Company ${ }^{1}$
}

\section{Elena Fedorova}

Doctor of Economics, Professor

ORCID

E-mail: ecolena@mail.ru

Department of Corporate Finance and Corporate Governance

Financial University under the Government of the Russian Federation, Moscow, Russia

\section{Yulia Grishchenko}

Candidate of Economic Sciences, Associate Professor

ORCID

E-mail: pochta2807@gmail.com

Department of Financial and Investment Management

Financial University under the Government of the Russian Federation, Moscow, Russia

\section{Igor Demin}

Doctor of Economics, Professor

ORCID

E-mail: idemin@fa.ru

Department of Data Analysis, Decision Making and Financial Technologies

Financial University under the Government of the Russian Federation, Moscow, Russia

\section{Elena Chernova}

Doctor of Economics, Professor, Administration

ORCID

E-mail: e.chernova@bk.ru

Department of Enterprise Economics and Entrepreneurship

St. Petersburg State University, St. Petersburg, Russia

Journal of Corporate Finance Research, Vol. 14, No. 2, pp. 22-34 (2020)

DOI: https://doi.org/10.17323/j.jcfr.2073-0438.14.2.2020.22-34

Received 10 April 2020 | Peer-reviewed 12 May 2020 | Accepted 24 May 2020

1 This article is based on the results of budgetary-supported research according to the state task carried out by the Financial University in 2019 on the topic "Ensuring the economic growth rate by increasing the attractiveness of domestic issuers", by the Financial University, Moscow, Russia. 


\section{Assessment of the Impact of the Level of Disclosure of Mandatory Non-Financial Information in Public Annual Reports on the Investment Attractiveness of a Company ${ }^{1}$}

\section{Abstract}

In this study, we assess the influence of information disclosed by issuers in annual reports in accordance with the requirements of the Central Bank of Russia on the investment attractiveness of a company.

The empirical base of the research consists of annual reports of 60 Russian issuers from various industries over 10 years. On the basis of applicable regulations of the Bank of Russia we compiled an author's dictionary of terms (word forms). Using the methods of taking into consideration grammatical forms we calculated occurrences of the dictionary terms in the texts of annual reports. This study represents the first time that a rating of issuers on the basis of the disclosure index of mandatory non-financial information (INDEX) in accordance with the Russian legislation was made. By means of a probit regression we proved the interrelation between the disclosure index of mandatory non-financial information (INDEX) and the issuer's investment attractiveness. Additionally, by means of a panel regression we established the interrelation between the issuer's investment attractiveness and the level of information disclosure which characterises the issuer, its securities and dividend policy, and its risk management policy.

Key words: non-financial reporting, text analysis, investment attractiveness, issuer, text analysis JEL classification: C33, D22, G32

1 This article is based on the results of budgetary-supported research according to the state task carried out by the Financial University in 2019 on the topic "Ensuring the economic growth rate by increasing the attractiveness of domestic issuers", by the Financial University, Moscow, Russia. 


\section{Introduction}

The transparency of information provided by issuers in public annual reports, and the completeness of its disclosure, are significant issues of discussion within the circles of professional business. In many countries worldwide, disclosure of non-financial information by issuers is voluntary. As for Russia, in accordance with its legislation, securities issuers are obliged to provide access for shareholders to financial and non-financial information. The reliability of an issuer's financial statements is confirmed annually by audit companies in accordance with the 'Federal Law of 30.12.2008 No. 307-FZ on Auditing'. Meanwhile, non-financial information regarding company operations is not subject to audit, is controlled by a regulator, and is disclosed in the issuer's public annual report in accordance with the requirements established by the Bank of Russia. The Regulations on Information Disclosure by Public Securities' Issuers (approved by the Bank of Russia on 30.12.2014 under No. 454-P) [1] establish the order, manner, time limits, and also define the type of financial and non-financial information subject to mandatory disclosure in the issuer's public annual report. The issuer's public annual report, along with information related to economic issues, contains data concerning non-financial aspects of the issuer's operations (development plans, the industry sector characteristics, risks, dividend policy, management principles etc.). It should be noted that this topic is of relevance at present, as the 'Law on Public Non-Financial Statements' was developed within the 'Concept of Development of Public Non-Financial Statements' approved by order of the government of the Russian Federation of 05.05.2017 No. 876-r.

The purpose of our research is to assess the influence of the disclosure index of mandatory non-financial information (INDEX) on companies (in accordance with the Russian legislation) regarding the attractiveness of their investment. Multiple research studies dedicated to this issue have explained the disclosure of non-financial information from the point of view of social-political and economic theories (agency theory, new institutional theory etc.) and, from the empirical point of view, proved the influence of non-financial information disclosure on the capital structure [2], share price [3], corporate operations performance [4] etc. In our research, on the one hand, we continue along the path of previous studies by considering standard issues of influence of non-financial information disclosure on corporate investment attractiveness. However, on the other hand, our research is different: 1) this study represents virtually the first time when the issue of influence of disclosure of certain categories of non-financial information on the attractiveness of corporate investment in accordance with the Russian legislation is considered; 2) we offer a methodology of calculation of the disclosure index of mandatory non-financial information (INDEX) in accordance with the Russian legislation, and compile an author's dictionary of word forms which allows for evaluation of the information disclosure level; and 3) we provide a rating of the best and worst issuers according to the disclosure index of mandatory non-financial information (INDEX).

\section{Literature Review}

In accordance with the requirements of Russian legislation and the established international practice of standardising non-financial information disclosure, the annual reports of public companies contain mandatory financial information, strategic information, information which characterises sales markets, company forecast development, information on management and supervision bodies, business risks, significant corporate actions, environmental pollution, human resource management policy, etc. V.E. Udaltsov and N.M. Tikhonova [5] assert that voluntary disclosure may increase the liquidity of shares, and reduces cost of capital, while the level of information disclosure quality notifies investors of the business development strategy.

At present, there are various empirical research studies which evaluate the influence of non-financial information on the issuer's financial attractiveness. In the paper [6] it was proposed that transparency and information disclosure influence corporate performance (as measured by means of Tobin's $Q$ and return on equity). Z. Rezaee and L. Tuo [7] proved the relation between non-financial information disclosure and leadership indicators in a sector after analysing 2,525 companies in four sectors in the United States of America in 2010 (the chemical industry, machine-building, electronics, and consulting services) on the basis of a panel regression. D. Mathuva and J.M. Kiweu [8] register the relation between the disclosure of social and environmental information and financial indicators for 215 savings and credit cooperatives in Kenya. A. Pavlopoulosa et al. [9], in their research, consider the relation between the quality of disclosure of integrated reporting and the profitability of a company.

In line with the abovementioned research studies, we assume that non-financial information disclosure also influences corporate financial indicators, as expressed through the level of attractiveness of corporate investment. Consequently, the mandatory non-financial information disclosed by issuers in public (non-financial) statements in general, and by groups in accordance with the requirements of the Bank of Russia is significant and influences the issuer's investment attractiveness.

\section{Research Methodology}

In order to assess an issuers' non-financial indicators and enhance their investment attractiveness, since 2014 the Russian Union of Industrialists and Entrepreneurs has been developing some domestic sustainable development indexes, being 'Responsibility and Transparency', and the 'Sustainable Development Vector'2. In 2019 the Russian

${ }^{2}$ URL: http://pспп.pф/simplepage/indeksy-i-reytingi-v-oblasti-uctoychivogo-razvitiya-i-korporativnoy-otvetstvennosti/ 
Union of Industrialists and Entrepreneurs and MICEX together defined the MRRT index Responsibility and Transparency3. The existing financial ratings in Russia (for example, RBC-5004, Expert 4005) comprise such indicators as profit before tax, volume of sales, net profit, and capitalisation. In its turn, the disclosed non-financial information is not included in the rating calculation.

Foreign authors use specialised dictionaries or bags of words in order to assess the level of non-financial information disclosure. At present, dictionaries in English have been developed for text analysis aimed at the evaluation of non-financial information disclosure. For example, the Dictionary of Economic and Social Value Orientation of a Company by T. Moss et al. [10], and the Corporate Social Responsibility Dictionary by N. Pencle and I. Mălăescu [11].

In this research, we offer the author's disclosure index of mandatory non-financial information (INDEX) of an issuer complying with the requirements of the Bank of Russia and based upon a technique similar to the 'western' one, which was applied to compile the author's dictionary of terms. The offered author's dictionary of terms was constructed according to expertise on the basis of requirements established in those laws and statutory instruments which regulate the manner of disclosure of non-financial information by issuers in annual reports. These instruments include:

- $\quad$ Regulations of the Bank of Russia of 30.12.2014 No. 454-P on Information Disclosure by Issuers of Public Securities [1];

- $\quad$ Letter of the Bank of Russia of 17.02.2016 No. IN-0652/8 on Disclosure in the Annual Report of a Public Joint-Stock Company of the Report on Compliance with the Principles and Recommendations of the Corporate Governance Code [12].

At the first stage, we selected the terms which characterise the issuer's operations, and are subject to mandatory disclosure in annual reports. For example, art. 70.3 of section VII of Regulations No. 454-P establish that the annual report of a joint-stock company should contain "...the information on the amount of each type of energy resource (atomic power, thermal power, electrical power, electromagnetic energy, oil, motor gasoline, diesel fuel, industrial fuel oil, rock (natural) gas, coal, shale coal, peat, etc.) used by the joint-stock company in the reporting year in natural units and in monetary terms".

At the second stage, on the basis of an analysis of the issuers' annual reports, we distinguished the most widespread and relevant word forms. The first group of terms A1 Company Operations Characteristics (Table 1) comprised

the terms related to the issuer's energy resources: "petrol, water, water supply, fuel and lubricants, diesel fuel, diesel oil, thermal power, heat energy, electrical power, electricity, and energy resources". The other groups of terms of the author's dictionary (A2, A3, A4, A5, A6, A6, A7, A8) were formed in the same way.

Table 1. The Author's dictionary of terms, compiled on the basis of legislative instruments of the Bank of Russia ${ }^{6}$

\section{Company operations characteristic (A1)}

Petrol, water, water supply, fuel and lubricants, diesel fuel, diesel oil, thermal power, heat energy, electrical power, electricity, energy resources; investment program, performance indicators, priority development fields, operating results; mission, future operations plans, forecast, development program, strategic targets, development strategy, growth strategy, revenue, year's results, company today, industry profile, mark review, position in the industry, company position in the industry, profitability, sales markets, events of the year, trends of the sector development, loss, financial indicators, financial performance, net profit, types of activity, lines of business, investment mediums, main business

\section{Securities and divi-} dend policy (A2)

Shareholders with an ownership share, redemption of shares, guarantee of rights, stock holders, protection of shareholders' rights, golden share, number of shares in circulation, number of shareholders, principal shareholder, number of minority shareholders, non-controlling shareholders, nominal value of ordinary shares, shareholder rights, preferred shares, shareholder meetings, shareholders' agreement, shareholder's structure, equity holding structure, capital structure, dividend amount, dividend distribution, payment date, declaration date, dividend yield, dividend history, dividend policy, company capitalisation, credit ratings, unpaid dividend, report on dividend payment, dividend amount, dividend amount per share, amount of declared dividend, amount of declared dividend in aggregate

3 URL: https://www.moex.com/ru/index/MRRT

4 URL: https://www.rbc.ru/rbc500/

5 URL: https://expert.ru/dossier/rating/expert-400/

6 Regulations on Information Disclosure by Public Securities Issuers (approved by the Bank of Russia on 30.12.2014 No. 454-P), Letter of the Bank of Russia of 17.02.2016 No. IN-06-52/8 On Disclosure in the Annual Report of a Public Joint-Stock Company of the Report on Compliance with the Principles and Recommendations of the Corporate Governance Code. 


\begin{tabular}{|c|c|}
\hline $\begin{array}{l}\text { Company operations } \\
\text { characteristic (A1) }\end{array}$ & $\begin{array}{l}\text { Securities and divi- } \\
\text { dend policy (A2) }\end{array}$ \\
\hline $\begin{array}{l}\text { Risk management } \\
\text { (A7) }\end{array}$ & $\begin{array}{l}\text { Management bodies } \\
\text { (A4) }\end{array}$ \\
\hline $\begin{array}{l}\text { Principal risks, significant } \\
\text { risks, risk factor, reputa- } \\
\text { tional risk, competition } \\
\text { risk, } \\
\text { loss of goodwill risk, risk } \\
\text { of failure to implement } \\
\text { the investment program, } \\
\text { risks associated with the } \\
\text { issuer's operations, judicial } \\
\text { disputes, price change, } \\
\text { operational risks, social } \\
\text { risks, price risks, legal } \\
\text { risk, legal risks, political } \\
\text { situation, regional risks, } \\
\text { sanctions, country risks, } \\
\text { economic environment, } \\
\text { currency risks, liquidity } \\
\text { risks, risks of exchange } \\
\text { rate growth, interest rate } \\
\text { increase, financial risks, } \\
\text { strategy risk }\end{array}$ & $\begin{array}{l}\text { Types of remuneration, } \\
\text { remuneration in money, } \\
\text { ordinary shares award, } \\
\text { annual bonus award, ad- } \\
\text { ditional remuneration, re- } \\
\text { imbursement for expenses, } \\
\text { principal remuneration, } \\
\text { remuneration amount, } \\
\text { remuneration to manage- } \\
\text { ment, management bodies } \\
\text { remuneration, remunera- } \\
\text { tions to executive bodies' } \\
\text { members, remuneration } \\
\text { to board members, board } \\
\text { members' revenues, sal- } \\
\text { ary, commission charge, } \\
\text { premiums, information on } \\
\text { cumulative remuneration, } \\
\text { chief executive officer, } \\
\text { year of birth, date of birth, } \\
\text { chairman, president, } \\
\text { controlling company, } \\
\text { biographical details of the } \\
\text { board members, biograph- } \\
\text { ical details, biography, } \\
\text { biography details of the } \\
\text { board members, owner- } \\
\text { ship of shares by the board } \\
\text { members, interest in the } \\
\text { authorised capital, share } \\
\text { of the board members in } \\
\text { the authorised capital, } \\
\text { background profile, carve- } \\
\text { out of shares by members, } \\
\text { obtaining of shares by } \\
\text { members, acquisition of } \\
\text { shares by members, sale } \\
\text { of shares by members, } \\
\text { information on transac- } \\
\text { tions made by members } \\
\text { of the board of directors, } \\
\text { president, board members, } \\
\text { of directors }\end{array}$ \\
\hline
\end{tabular}

\begin{tabular}{|c|c|}
\hline $\begin{array}{l}\text { Company operations } \\
\text { characteristic (A1) }\end{array}$ & $\begin{array}{l}\text { Securities and divi- } \\
\text { dend policy (A2) }\end{array}$ \\
\hline $\begin{array}{l}\text { Corporate management } \\
\text { (principles) (A5) }\end{array}$ & $\begin{array}{l}\text { Control bodies, control } \\
\text { (A6) }\end{array}$ \\
\hline $\begin{array}{l}\text { Corporate governance } \\
\text { code, } \\
\text { company secretary, board } \\
\text { secretary, corporate gover- } \\
\text { nance principles, compli- } \\
\text { ance with principles, key } \\
\text { principles and recom- } \\
\text { mendations of the code, } \\
\text { report on compliance } \\
\text { with principles, report on } \\
\text { compliance with principles } \\
\text { and recommendations of } \\
\text { the code }\end{array}$ & $\begin{array}{l}\text { Internal audit, internal } \\
\text { audit directorate, audit } \\
\text { committee, audit com- } \\
\text { mittee report, revision } \\
\text { commission, internal con- } \\
\text { trol, corporate insurance, } \\
\text { corporate-wide system of } \\
\text { risk management, CSRM, } \\
\text { issuer's risk management } \\
\text { policy, risk portfolio, risk } \\
\text { management practice, } \\
\text { risk management process, } \\
\text { development of the risk } \\
\text { management system, risk } \\
\text { appetite, risk manage- } \\
\text { ment, ICS, internal control } \\
\text { system, risk management } \\
\text { system, risk management } \\
\text { and internal control sys- } \\
\text { tem, RMS, RMaICS, risk } \\
\text { management }\end{array}$ \\
\hline $\begin{array}{l}\text { Information on transac- } \\
\text { tions } \\
\text { (A3) }\end{array}$ & $\begin{array}{l}\text { Others, mandatory dis- } \\
\text { closure } \\
\text { (A8) }\end{array}$ \\
\hline $\begin{array}{l}\text { Major deals, } \\
\text { interested-party transac- } \\
\text { tions }\end{array}$ & $\begin{array}{l}\text { Information policy, infor- } \\
\text { mation disclosure, annual } \\
\text { report has been approved, } \\
\text { approved by resolution of, } \\
\text { approval of the annual re- } \\
\text { port, reorganisation, major } \\
\text { corporate actions, major } \\
\text { transaction }\end{array}$ \\
\hline
\end{tabular}

Source: Author's own research.

The author's disclosure comprises 186 terms subdivided into eight groups (Figure 1). It is clear from Figure 1 that the majority of terms of the author's dictionary, i.e. 41 terms, belong to the "first group" (A1) and they characterise the issuer's operations, the amount of the used type of energy resource in natural units and in monetary terms, information on the report of the board of directors, development prospects, position in the industry sector, and priority lines of business. The "second group" (A2) comprises 34 terms which characterise the issuer's securities, its dividend policy, and the issuer's interaction with shareholders. The "fourth group" (A4) consists of 40 terms. The information is related to bibliographic data and remuneration of company management. The smallest number of terms comprises the "third group" (A3) and includes the following word forms: major deals, interested-party transactions, etc. 
Figure 1. Structure of the author's dictionary by the number of terms in a group

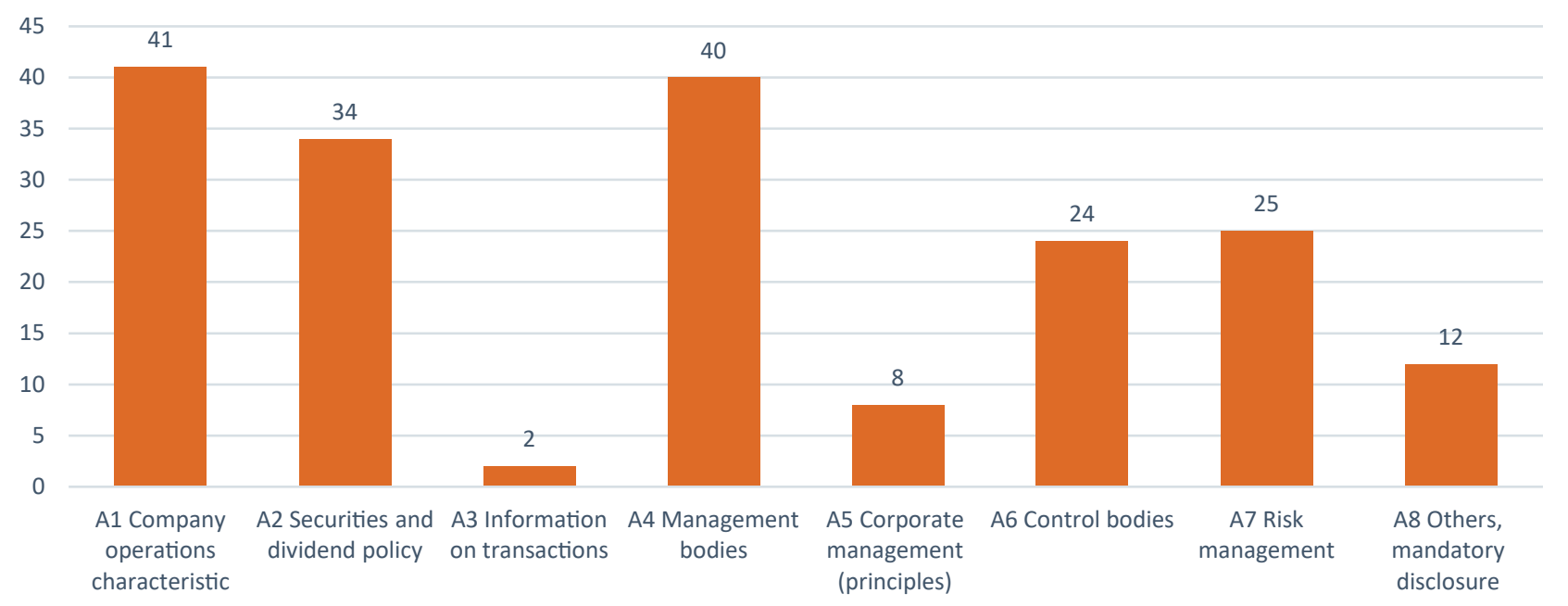

Source: Author's own research.

At the third stage, we calculated the number of dictionary terms in the companies' annual reports from the point of view of individual groups. It is impossible to implement this procedure applying ordinary text search method, because in the Russian language, virtually every term has several variations. For example, the dictionary term "dividend policy" may be used in texts in the forms "dividend policy" or "dividend policies". We needed a method which takes all possible word forms into consideration.

'Stemming' is one such method. The essence of stemming consists in abridgement of each word up to its unchangeable stem. For example, the words in the terms "dividend policy" will be abridged up to "dividend- polic-“. Further, we can perform the same actions with the text in which we are going to search for terms, then we will look exactly for such a line of text, or use for our search the pattern "dividend ${ }^{\star}$ polic ${ }^{*}$ " where "* " sign stands for any characters. At the same time, stemming yields good results only with long words. For example, if we take a word such as "rights", after stemming it turns into "right-".

Another widely spread method of taking into consideration grammatical forms is lemmatisation, which transforms all words both from search request and contained in the text in which the search is performed into their root form.

Lemmatisation greatly reduces ambiguity, but it cannot eliminate it completely due to homoforms. So, the word "rights" may be a form of both: the noun "right" (stakeholders' rights) and the verb "to right" (he rights the committed wrong). It depends on the context in which source form a word should be transformed in each individual situation, as a wrong transformation may be the reason for errors in the search. All this requires a serious manual control when reporting documents are lemmatised.

In order to avoid such problems, we decided to apply another method. The reporting documents were not changed as regards word forms. We performed only evident technical changes: the letters were written in lower case, non-alphabetic characters were eliminated, and spaces were unified. This latter operation was necessary because annual reports are often presented not as a plain text but as a result of a professional designer's page makeup which, instead of spaces, may divide sentences with other symbols: page break, column break etc.

As long as word forms in a text were unchanged it was necessary to search for all possible word forms of dictionary entries. Therefore, a request was a regular expression which allowed to search for all such forms. For example, a regular expression for the entry "principal shareholder" searched for possible forms "principal shareholders", "principal shareholder's", and "principal shareholders" (in Russian there are 10 word forms). All possible word forms were included automatically on the basis of the OpenCorpora dictionary, and therefore the possible homoforms were controlled manually. This was possible because the number of entries was small. In difficult cases the requests were also corrected manually: for example, in economic texts the term "risk management" may be written with a hyphen instead of a space. This method enabled us to automatically calculate the occurrence of dictionary terms in the annual reports' texts, avoiding distortion of the results.

The dictionary developed in this way became a part of the rulexicon library in the $\mathrm{R}$ environment. Below we provide an example of it in use. In order to calculate the terms occurrence, it is necessary to download the library.

1 \#install.packages('devtools')

2 devtools::install_github('dmafanasyev/rulexicon')

Then we have to use the table with the dictionary. The next code line downloads the data into the variable keytable.

1 keytable=rulexicon::key_company_rus_report_standard

The data is of the following structure:

order

number of the group of terms (1 - A1, $2-\mathrm{A} 2$ etc.)

section

name of the group of terms 


\section{main_token}

the main indicator: some key notion, information about which we should find in the text, for example, "development prospects"

\section{token}

a term: a certain word of the word combination which should be found in the text within the main indicator; thus, for the main indicator "development prospects" the terms "development strategy", "growth strategy", "development program", "strategic objectives" etc. will be such terms

regex

a regular expression which contains all possible word forms of this term

The next code loads the stringr library for text processing and then it loads one of the annual reports into the text variable, in the example given it is a report of VTB Bank for 2018. The text lines are combined into one line and then the text is presented in lower case letters:

\section{1 library(stringr)}

2 text <- readLines('https://raw.githubusercontent.com/ isdemin/repstandart/master/BankVTB2018.txt',

3 encoding = 'UTF-8') \%> paste $($ collapse = ' ') $\%>\%$ tolower

Further on the basis of regular expressions, the number of occurrences of each term in the text is calculated. The total number of terms is presented from the point of view of term groups:

1 occurencies <- str_count(text, keytable\$regex)

2 by(occurencies, keytable\$section, sum)

The result of this code execution is stated below: keytable\$section: Corporate management (principles) [1] 99

keytable\$section: Control bodies

[1] 294

keytable\$section: Management bodies

[1] 718

keytable\$section: Others, mandatory disclosure [1] 44

keytable\$section: Information on transactions [1] 2 keytable\$section: Risk management

[1] 59

keytable\$section: Company Operations Characteristic

[1] 252

keytable\$section: Securities and dividend policy

[1] 218

It can be observed that in this annual report all term groups are presented, however it is done unequally: the largest group is Management Bodies (718 occurrences), the smallest is Information on Transactions (2 occurrences). Thus, using the library does not imply lemmatisation and tokenisation of texts. A simple and short code performs the work. The 8 obtained index numbers calculated for each annual report were the values of variables A1A8, upon which the subsequent data analysis is based. Calculation of the value of the disclosure index of mandatory non-financial information (INDEX), developed on the basis of the author's dictionary may be described as follows:

$\mathrm{INDEX}=\sum \mathrm{A} 1+\mathrm{A} 2+\mathrm{A} 3+\mathrm{A} 4+\mathrm{A} 5+\mathrm{A} 6+\mathrm{A} 7+\mathrm{A} 8$, where $A 1$ is the group of terms Company Operations Characteristic;

A2 is the group of terms Securities and Dividend Policy; A3 is the group of terms Information on Transactions; A4 is the group of terms Management Bodies; A5 is the group of terms Corporate Management (principles);

A6 is the group of terms Control Bodies;

A7 is the group of terms Risk Management;

A8 is the group of terms Others, Mandatory Disclosure.

The obtained index belongs within the final model of assessment of the influence of non-financial information on the attractiveness of corporate investment.

The research methodology comprised the panel regression and Logit-model. Tobin's $\mathrm{Q}$ ratio represented in the papers $[6 ; 13 ; 14]$, was used as a dependent variable (investment attractiveness) and it is calculated by the following formula:

Tobin's $\mathrm{Q}=($ Market capitalisation + Obligations + Preferred shares + Ownership interest in a subsidiary)/Total assets. (1)

We chose the following indicators of financial standing and market performance as control variables: return on assets (X1), return on equity (X2), weighed average capital cost (X3), economic value added (X4), assets (X5), weighed average share price by volume (X6), and share price / earnings per share ratio (X7). 


\section{Data Analysis}

The empirical database of the research comprised 600 annual reports of the issuers for the period of 2009 to 2018, and 60 public Russian companies with the greatest capitalisation and listed at the Moscow Stock Exchange.

Let us consider the results of evaluation of the index (INDEX) of the studied groups in annual reports of the issuers in more detail (Figure 2).

On the basis of the results of our evaluation of the disclosure index of mandatory non-financial information (INDEX) we drew up ratings, ranking the best and worst annual reports of issuers for 2018. The leaders of the rat- ing of the best issuers' reports on the basis of the amount of disclosure of mandatory information in annual reports for 2018 are represented in Table 2. Half of the issuers included in the rating of the best issuers' reports are energy providers. The top three in the rankings comprises companies with state participation. The Federal Grid Company of Unified Energy System (FGS UES) is the first in the rating, and its index (INDEX) for 2018 is 2,865. Inter RAO and MOESK (Moscow United Electric Grid Company) occupy the second and third place respectively, and the disclosure index (INDEX) of MOESK is smaller than the one of the company, occupying the second place, by four terms and amounts to 2,395.

Figure 2. Dynamics of mandatory information disclosure in annual reports as regards aggregated data for the period of 2009 to 2018 (number of terms)

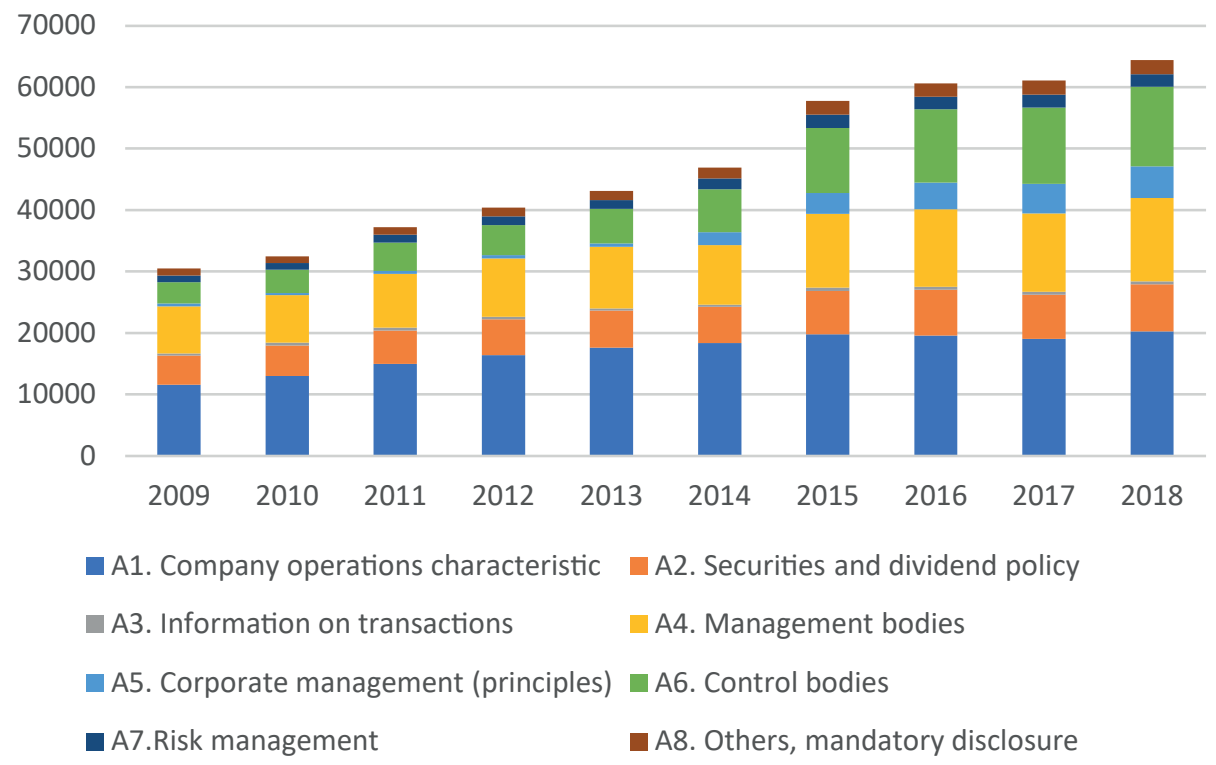

Source: Author's own research.

Table 2. Ratings of the best public reports of issuers as regards the index (INDEX) for 2018 (number of terms)

\begin{tabular}{|c|c|c|c|c|c|c|c|c|c|c|c|c|}
\hline No. & $\begin{array}{l}\text { Company } \\
\text { name (short) }\end{array}$ & Industry & A1 & A2 & A3 & A4 & A5 & A6 & A7 & A8 & INDEX & Tobin's Q \\
\hline 1 & $\begin{array}{l}\text { Federal Grid } \\
\text { Company of } \\
\text { Unified Energy } \\
\text { System (FGS } \\
\text { UES) }\end{array}$ & $\begin{array}{l}\text { Power } \\
\text { industry }\end{array}$ & 999 & 232 & 53 & 472 & 348 & 570 & 33 & 158 & 2,865 & 0.46 \\
\hline 2 & Inter RAO & $\begin{array}{l}\text { Power } \\
\text { industry }\end{array}$ & 1,131 & 158 & 12 & 294 & 303 & 383 & 41 & 77 & 2,399 & 0.73 \\
\hline 3 & $\begin{array}{l}\text { MOESK (Mos- } \\
\text { cow United } \\
\text { Electric Grid } \\
\text { Company) }\end{array}$ & $\begin{array}{l}\text { Power } \\
\text { industry }\end{array}$ & 867 & 260 & 11 & 532 & 78 & 520 & 38 & 89 & 2,395 & 0.59 \\
\hline 4 & $\begin{array}{l}\text { NORILSK } \\
\text { NIKEL }\end{array}$ & $\begin{array}{l}\text { Metallurgy } \\
\text { industry }\end{array}$ & 614 & 215 & 12 & 413 & 292 & 451 & 68 & 63 & 2,128 & 2.73 \\
\hline
\end{tabular}




\begin{tabular}{|c|c|c|c|c|c|c|c|c|c|c|c|c|}
\hline No. & $\begin{array}{l}\text { Company } \\
\text { name (short) }\end{array}$ & Industry & A1 & $\mathbf{A} 2$ & A3 & A4 & A5 & A6 & A7 & A8 & INDEX & Tobin's Q \\
\hline 5 & AEROFLOT & Transport & 815 & 173 & 16 & 417 & 195 & 371 & 45 & 73 & 2,105 & 1.18 \\
\hline 6 & LENENERGO & $\begin{array}{l}\text { Power } \\
\text { industry }\end{array}$ & 660 & 193 & 9 & 438 & 54 & 480 & 43 & 81 & 1,958 & 0.59 \\
\hline 7 & VTB BANK & Banks & 252 & 218 & 2 & 718 & 99 & 294 & 59 & 44 & 1,686 & 0.97 \\
\hline 8 & $\begin{array}{l}\text { TATNETF n.a. } \\
\text { V.D.SHASHIN }\end{array}$ & $\begin{array}{l}\text { Oil and } \\
\text { gas }\end{array}$ & 695 & 247 & 6 & 255 & 77 & 232 & 68 & 47 & 1,627 & 1.65 \\
\hline 9 & $\begin{array}{l}\text { KUBANEN- } \\
\text { ERGO }\end{array}$ & $\begin{array}{l}\text { Power } \\
\text { industry }\end{array}$ & 627 & 128 & 6 & 275 & 78 & 407 & 21 & 65 & 1,607 & 0.79 \\
\hline 10 & LUKOIL & $\begin{array}{l}\text { Oil and } \\
\text { gas }\end{array}$ & 511 & 158 & 5 & 428 & 65 & 312 & 57 & 41 & 1,577 & 0.90 \\
\hline
\end{tabular}

Source: Author's own research.

Table 3 presents the rating of the worst issuers, according to the disclosure index of mandatory information in annual reports for 2018. The companies from this rating have different industry specialisation and comprise machine building, trade and retail, transport, metallurgy industry, power industry, etc. However, it should be noted that all studied issuers' annual reports contain the minimum allowed number of terms, i.e. 186.

The company SOLLERS is the first in the rating, and their term frequency in the annual report amounts to 199 terms. Assessing the quality of terms disclosure, it is necessary to compare the number of terms in the author's dictionary and the obtained frequency results. Group A8 in the author's dictionary consists of 12 terms, and the term frequency in the "eighth group" in the annual reports made by such companies as SOLLERS, LENTA and Magnitogorsk Iron and Steel Works (MMK) is 3. The frequency for IRKUT CORPORATION and UTAIR is 2. Nevertheless, the obtained results do not imply that the companies fail to disclose other mandatory information and do not comply with the obligatory requirements of the Bank of Russia. The "eighth group" (group A8) of terms comprises synonyms and terms which characterise irregular business operations of the issuer, for example: reorganisation, major corporate actions, and major transactions.

The results of frequency in the "second group" (A2) of terms obtained by analysis of the annual report made by LENTA are of special interest. The "second group" (A2) of the author's dictionary comprises 34 terms. The frequency in this group for the company LENTA amounts to 4 terms, which is 30 less than the necessary number of occurrences. The obtained results may be contingent upon a low quality of information disclosure in the corporate annual report and a failure to meet the required regulations of the Bank of Russia. In order to make well-founded conclusions it is necessary to investigate the annual report of LENTA for 2018 in great detail and identify the factors which influence the discovered deviations.

The annual report of LENTA for 2018 is drawn up on 146 pages. The information on the issuer's securities is presented on pages 122-123. The issuer discloses the following information: number of shares in circulation, types of shares, and information on the shares' issue. The testing results showed that the following terms were not mentioned in the report: amount of dividends, payment date, declaration date, dividend yield, dividend history, dividend policy. The obtained results are contingent upon the fact that the company issued shares without a nominal value. In implementing the Long-Term Incentive Program for business units' directors, dividends on ordinary shares in 2018 and 2017 were not declared. The information on the dividend policy is presented in the report as follows: "In accordance with British Virgin Islands Business Companies Act No. 16 of 2004 dividends may be declared and paid only if the Board of Directors confirms that immediately after dividend payment the Group will be able to fulfill the assumed obligations within the established period and in the ordinary course of business, and that the Group assets in case of their sale will not be less than the aggregate amount of obligations after deduction of deferred taxes stated in the accounting reports and its capital value". Thus, it can be affirmed that the information on the corporate dividend policy is disclosed in the annual report. 
Table 3. Rating of the best issuers' reports as regards frequency of term disclosure for 2018 (number of terms)

\begin{tabular}{|c|c|c|c|c|c|c|c|c|c|c|c|c|}
\hline No. & $\begin{array}{l}\text { Company } \\
\text { name (short) }\end{array}$ & Industry & A1 & A2 & A3 & A4 & A5 & A6 & A7 & A8 & INDEX & Tobin's Q \\
\hline 1 & SOLLERS & $\begin{array}{l}\text { Machine } \\
\text { building }\end{array}$ & 36 & 40 & 5 & 68 & 7 & 18 & 22 & 3 & 199 & 0.91 \\
\hline 2 & LENTA & $\begin{array}{l}\text { Trade and } \\
\text { retail }\end{array}$ & 72 & 4 & 18 & 53 & 3 & 11 & 56 & 3 & 220 & 1.08 \\
\hline 3 & $\begin{array}{l}\text { IRKUT COR- } \\
\text { PORATION }\end{array}$ & $\begin{array}{l}\text { Machine } \\
\text { building }\end{array}$ & 67 & 57 & 3 & 56 & 11 & 35 & 39 & 2 & 270 & 1.07 \\
\hline 4 & UTAIR & Transport & 52 & 55 & 3 & 109 & 17 & 49 & 15 & 2 & 302 & 1.76 \\
\hline 5 & $\begin{array}{l}\text { IRKUTSEN- } \\
\text { ERGO }\end{array}$ & $\begin{array}{l}\text { Power } \\
\text { industry }\end{array}$ & 28 & 48 & 12 & 71 & 33 & 91 & 2 & 23 & 308 & 0.99 \\
\hline 6 & $\begin{array}{l}\text { KUIBY- } \\
\text { SHEVAZOT }\end{array}$ & $\begin{array}{l}\text { Chemical } \\
\text { industry }\end{array}$ & 110 & 70 & 7 & 72 & 13 & 48 & 24 & 8 & 352 & 0.82 \\
\hline 7 & $\begin{array}{l}\text { Magnitogorsk } \\
\text { Iron and } \\
\text { Steel Works } \\
(\mathrm{MMK})\end{array}$ & $\begin{array}{l}\text { Metallurgy } \\
\text { industry }\end{array}$ & 117 & 85 & 1 & 85 & 13 & 79 & 15 & 3 & 398 & 1.27 \\
\hline 8 & $\begin{array}{l}\text { VSM- } \\
\text { PO-AVISMA }\end{array}$ & $\begin{array}{l}\text { Metallurgy } \\
\text { industry }\end{array}$ & 76 & 60 & 8 & 116 & 20 & 75 & 27 & 16 & 398 & 1.00 \\
\hline 9 & MECHEL & $\begin{array}{l}\text { Metallurgy } \\
\text { industry }\end{array}$ & 80 & 79 & 4 & 110 & 19 & 94 & 27 & 6 & 419 & 1.86 \\
\hline 10 & $\begin{array}{l}\text { SURGUT- } \\
\text { NEFTEGAS }\end{array}$ & Oil and gas & 133 & 77 & 3 & 73 & 17 & 82 & 19 & 17 & 421 & 0.33 \\
\hline
\end{tabular}

Source: Author's own research.

The obtained results of our analysis, performed on public information disclosure in issuers' annual reports, brings us to the conclusion that the level of its disclosure is in accordance with the requirements of the Bank of Russia. In cases when the disclosure index (INDEX) is below the minimum value it is necessary to carry out additional analysis of the issuers' public reports. This is fundamentally to identify the factors which influence the absence from the issuers' reports of information subject to mandatory disclosure in accordance with the applicable requirements.

\section{Main Research Results and Discussion}

Using the Logit-model, we select from the aggregate and define the significant indicators which influence the issuer's financial attractiveness. The obtained results are represented in Table 4 and show the presence of a statistically significant interrelation.

Table 4. Results of assessment of the Logit-model of the issuer's investment attractiveness for the period from 2009 to 2018

\begin{tabular}{|c|c|c|c|c|}
\hline Variable & Ratio & Standard error & Z-statistics & Significance \\
\hline INDEX & -0.000862 & 0.000187 & -4.603109 & 0.0000 \\
\hline $\mathrm{X} 1$ & 0.013588 & 0.003712 & 3.660357 & 0.0003 \\
\hline $\mathrm{X} 3$ & 0.087259 & 0.026963 & 3.236244 & 0.0012 \\
\hline $\mathrm{X} 4$ & $4.86 \mathrm{E}-12$ & $1.51 \mathrm{E}-12$ & 3.212370 & 0.0013 \\
\hline X6 & 0.000501 & 0.000125 & 4.007582 & 0.0001 \\
\hline const & -0.356094 & 0.286890 & -1.241219 & 0.2145 \\
\hline
\end{tabular}

Source: Author's own research. 
On the basis of the constructed model we can conclude that the studied variables are an important factor when investment decisions are taken. The negative interrelation between the information disclosure index (INDEX) and Tobin's Q is contingent upon the fact that investors only pay attention to individual groups of terms which characterise risk management, securities, and the corporate dividend policy in the annual report, instead of the general disclosure of terms.

Out of the factors which we have considered, the information disclosure index (INDEX), return on assets, weighed average capital cost, economic value added, volume-weighted average price each have a significant impact on the issuer's attractiveness.

The obtained results are indicative of the fact that a company with a high Tobin's $Q$ has a low information disclosure index. On the contrary, companies with a low Tobin's $\mathrm{Q}$ have a high information disclosure index. As was stated in the research $[15 ; 16]$, on average the Tobin's $Q$ ratio is stable in time. The issuers which show its high value, as a rule, are successful and have unique production factors or manufacture unique products. However, companies which show a low Tobin's Q operate in competitive (regulated) industry sectors, and incompletely achieve the potential of their intellectual capital.
Thus, the greatest frequency of the information disclosure index, as a rule, is characteristic of the following industries: power industry, oil and gas. The obtained results are indicative of the fact that energy companies with state participation (PJSC ROSSETI) are in the top three companies of the information disclosure index (INDEX). As such, the Tobin's Q ratio of the energy companies included in the rating of the best companies concerning the information disclosure index is in the range of 0.46 to 0.79 . However, the energy provider IRKUTSENERGO (subsidiary of JSC EuroSibEnergo), included in the rating among the 'worst' reports, has a Tobin's Q ratio amounting to 0.99 , which is higher than the "best" energy companies.

We presume that companies with state participation have a more responsible attitude to the quality of disclosed non-financial information in the annual reports, while the Tobin's $Q$ ratio is contingent upon the regulated industry specifics of the issuer.

Further study is necessary for additional verification of the hypothesis which will define the groups of terms included in calculating the information disclosure index, and which have most influenced the obtained result. The results of making the panel regression are presented in Table 5.

Table 5. Results of making the panel regression with a random effect which defines influence of A1-A8 factors on the issuer's investment attractiveness

\begin{tabular}{|c|c|c|c|c|}
\hline Coefficients & Estimate Std & Error & z-value & $\operatorname{Pr}(>|z|)$ \\
\hline Const & $8.3302 \mathrm{e}-01$ & $9.4125 e-02$ & 8.8502 & $<2.2 \mathrm{e}-16^{* * *}$ \\
\hline A 1 & $-5.0451 \mathrm{e}-04$ & $1.6556 \mathrm{e}-04$ & -3.0473 & $0.002309^{* *}$ \\
\hline A2 & $2.1633 e-03$ & $1.6662 \mathrm{e}-03$ & 1.6983 & 0.104180 \\
\hline A7 & $3.2657 \mathrm{e}-03$ & $1.5024 \mathrm{e}-03$ & 2.1736 & $0.029732 *$ \\
\hline $\mathrm{X} 1$ & $6.5595 e-03$ & $2.7892 \mathrm{e}-03$ & 2.3518 & $0.018685^{*}$ \\
\hline $\mathrm{X} 3$ & $3.4682 \mathrm{e}-02$ & $6.5899 \mathrm{e}-03$ & 5.2628 & $1.418 \mathrm{e}-07^{\star * *}$ \\
\hline $\mathrm{X} 4$ & $3.5963 \mathrm{e}-13$ & $1.9683 \mathrm{e}-13$ & 1.8271 & 0.067680 \\
\hline $\mathrm{X} 5$ & $-2.1716 \mathrm{e}-14$ & $1.1431 \mathrm{e}-14$ & -1.8997 & 0.057469 \\
\hline $\mathrm{X} 6$ & $4.6573 e-05$ & $1.7961 \mathrm{e}-05$ & 2.5929 & $0.009516^{* *}$ \\
\hline
\end{tabular}

Source: Author's own research.

In order to choose the correct model specification, we applied the Hausman test. The zero hypothesis of the Hausman test consists in the fact that RE-model is better than the FE-model, and its alternative is that FE-model is better. We chose a model with random effects. Let us now consider the obtained results. First of all, we discuss the analysis of the individual statistical significance of each of the eight groups of terms (A1, A2, A3, A4, A5, A6, A7, and $A 8$ ), made on the basis of regulatory documents of the Bank of Russia, and included in the calculation the disclosure index of mandatory non-financial information (INDEX).
Testing showed that such variables as A3, A4, A5, A6, A8 turned out to be statistically insignificant. At the same time, a significant interrelation related to indicator 'A1 Company Operations Characteristic' (with a negative coefficient) is indicative of the fact that information disclosure in public annual reports influences the issuer's investment attractiveness. We also defined that pieces of important information for investors include data on securities and corporate dividend policy (A2 group), and issuer's operations risks (A7 group). Therefore, the relation between the studied indicators is positive.

Thus, the practical significance of the obtained results of 
the research consists in the fact that in order to increase the issuer's investment attractiveness, when preparing non-financial reports, the issuers have to pay special attention to the group of terms which characterise securities, dividend policy, and corporate risks.

\section{Conclusion}

Non-financial information on the issuer's operations is disclosed in the issuer's annual report in accordance with the requirements established by the Bank of Russia. The data disclosed in the public annual reports is a public information source for concerned parties on the efficiency of the issuer's operations. As such, the frequency of word forms disclosed in the text of an annual report of an issuer was used in order to evaluate the completeness of information disclosure in accordance with the Russian legislation.

On the basis of the author's disclosure index of mandatory non-financial information (INDEX) we calculated ratings of the worst and best companies in terms of information disclosure for 2018. We established that every issuers' annual reports contain the minimum permissible number of terms.

As a result of our research, we confirmed the underlying assumption that there is a relation between the disclosure index of mandatory non-financial information (INDEX) and the issuer's investment attractiveness. The negative interrelation between these indicators is contingent upon the fact that investors only pay attention to individual groups of terms, e.g. those which characterise risk management, securities, and the corporate dividend policy, instead of the general disclosure of terms in the annual report. After appraising the obtained results (concerning the power industry) we showed a negative interrelation between the indicators. We assume that the implication of the obtained results is that energy companies with state participation pay a lot of attention to information disclosure in annual reports, while the Tobin's $Q$ ratio being below 1 is contingent upon the regulated industry specifics.

\section{References}

1. Regulation on the disclosure of information by issuers of equity securities. Approved by the Bank of Russia on December 30, 2014 No. 454-P. URL: http://www.consultant.ru/document/cons_doc_ LAW_175536/ (In Russ.).

2. Christensen H.B., Hail L., Leuz C. Mandatory IFRS reporting and changes in enforcement. Journal of Accounting and Economics. 2013;56(2-3):147-177. DOI: $10.1016 /$ j.jacceco.2013.10.007

3. Callen J.L., Gavious I., Segal D. The complementary relationship between financial and non-financial information in the biotechnology industry and the degree of investor sophistication. Journal of Contemporary Accounting \& Economics. 2010;6(2):6176. DOI: 10.1016/j.jcae.2010.09.001

4. Wang S., Wang H., Wang J., Yang F. Does environmental information disclosure contribute to improve firm financial performance? An examination of the underlying mechanism. Science of the Total Environment. 2020;714:136855. DOI: 10.1016/j. scitotenv.2020.136855

5. Udaltsov V.E., Tikhonova N.M. Influence of informational transparency on the cost of capital and operational efficiency of Russian public companies. Korporativnye finansy = Journal of Corporate Finance Research. 2013;7(1):2-16. (In Russ.). DOI: 10.17323/j. jcfr.2073-0438.7.1.2013.2-16

6. Al-ahdal W.M., Alsamhi M.H., Tabash M.I., Farhan N.H.S. The impact of corporate governance on financial performance of Indian and GCC listed firms: An empirical investigation. Research in International Business and Finance. 2020;51:101083. DOI: 10.1016/j.ribaf.2019.101083

7. Rezaee Z., Tuo L. Voluntary disclosure of nonfinancial information and its association with sustainability performance. Advances in Accounting. 2017;39:47-59. DOI: 10.1016/j.adiac.2017.08.001

8. Mathuva D.M., Kiweu J.M. Cooperative social and environmental disclosure and financial performance of savings and credit cooperatives in Kenya. Advances in Accounting. 2016;35:197-206. DOI: 10.1016/j. adiac.2016.09.002

9. Pavlopoulos A., Magnis C., Iatridis G.E. Integrated reporting: An accounting disclosure tool for high quality financial reporting. Research in International Business and Finance. 2019;49:13-40. DOI: 10.1016/j. ribaf.2019.02.007

10. Moss T.W., Renko M., Block E., Meyskens M. Funding the story of hybrid ventures: Crowdfunder lending preferences and linguistic hybridity. Journal of Business Venturing. 2018;33(5):643-659. DOI: 10.1016/j.jbusvent.2017.12.004

11. Pencle N., Mălăescu I. What's in the words? Development and validation of a multidimensional dictionary for CSR and application using prospectuses. Journal of Emerging Technologies in Accounting. 2016;13(2):109-127. DOI: $10.2308 /$ jeta-51615

12. Letter of the Bank of Russia dated February 17, 2016 No. IN-06-52/8 "On the disclosure in the annual report of a public joint-stock company of a report on compliance with the principles and recommendations of the Corporate Governance Code". URL: https:// www.garant.ru/products/ipo/prime/doc/71237796/ (In Russ.). 
13. Gizatullin A.V. Corporate governance, social responsibility and financial efficiency of the company. Rossiiskii zhurnal menedzhmenta $=$ Russian Management Journal. 2007;5(1):35-66. (In Russ.).

14. Bose S., Saha A., Khan H.Z., Islam S. Non-financial disclosure and market-based firm performance: The initiation of financial inclusion. Journal of Contemporary Accounting \& Economics. 2017;13(3):263-281. DOI: 10.1016/j.jcae.2017.09.006

15. Kovalev V.V. The problem of terminological uncertainty in applied economics. Vestnik SanktPeterburgskogo universiteta. Ekonomika $=S t$ Petersburg University Journal of Economic Studies (SUJES). 2012;(1):3-19. (In Russ.).

16. Bregvadze D.T., Sokolyansky V.V., Knyazeva E.V. Tobin's $Q$ ratio as an indicator of investment attractiveness of space industry companies. Kreativnaya ekonomika $=$ Journal of Creative Economy. 2016;10(6):543-552. DOI: 10.18334/ ce.10.6.35334 